\title{
Kualitas Habitat Rekruitmen Juvenil Karang Di Perairan Pulau Kemujan, Karimunjawa
}

\author{
Kharisma Ayu Zeina Halisah*, Anhar Solichin, Aninditia Sabdaningsih \\ Departemen Sumberdaya Akuatik, Fakultas Perikanan dan Ilmu Kelautan Universitas Diponegoro \\ Jl. Prof. Soedarto, SH, Tembalang, Semarang, Jawa Tengah 50275 \\ Email: kharismaahalisah@gmail.com
}

\begin{abstract}
Abstrak
Pulau Kemujan merupakan salah satu pulau terbesar di Kepulauan Karimunjawa yang memiliki kerapatan terumbu karang yang beragam. Ekosistem terumbu karang memiliki peranan penting namun juga merupakan ekosistem yang rentan akan terjadinya kerusakan. Rekruitmen juvenil karang dapat terjadi karena penurunan daya dukung habitat terumbu karang, sebagai akibat penurunan kualitas perairan terdampak kegiatan antropogenik. Tujuan penelitian ini adalah untuk mengetahui densitas juvenil karang, kesesuaian faktor fisika, kimia dan biologi yang mempengaruhi proses penempelan juvenil karang, kondisi terumbu karang serta hubungan antara kelimpahan juvenil karang dengan tutupan karang dan bahan organik di perairan Pulau Kemujan. Metode pada penelitian ini adalah metode analisis deskriptif dengan pengumpulan data Line Intercept Transect (LIT) sepanjang 50 meter. Penelitian ini dilaksanakan pada Bulan November 2019 di sisi barat (S: 05 $46^{\prime} 07,4^{\prime \prime}$ dan E : $110^{\circ} 28^{\prime} 44,6^{\prime \prime}$ ) dan sisi timur (S: 0546’49,8” dan E : $\left.110^{\circ} 30^{\prime} 28,3^{\prime \prime}\right)$ Pulau Kemujan. Hasil yang diperoleh dari penelitian ini yaitu densitas juvenil karang tertinggi berada di daerah reef flat sisi barat (stasiun 1) perairan Pulau Kemujan sebanyak 0,44 koloni $/ \mathrm{m}^{2}$, sedangkan kelimpahan terendah berada di daerah reef slope sisi timur (stasiun 2) sebanyak $0,15 \mathrm{koloni} / \mathrm{m}^{2}$. Parameter fisika (kedalaman, kecerahan, kecepatan arus, suhu), kimia (DO, $\mathrm{pH}$, salinitas, bahan organik) dan biologi (total koloni bakteri) pada lokasi penelitian masih berada pada batas kisaran nilai optimum sesuai KepMen LH Nomor 51 Tahun 2004 . Kondisi tutupan karang hidup pada sisi barat perairan Pulau Kemujan berkisar dari 46,60\% hingga 53,62\% sedangkan pada sisi timur yaitu berkisar dari 44,10\% hingga 71,38\%. Hasil perbandingan antara densitas juvenil karang sebagai variabel terikat dengan tutupan karang hidup, pecahan karang serta bahan organik sebagai variabel bebas menunjukkan pola hubungan yang berbanding terbalik sedangkan dengan tutupan karang mati berbanding lurus. Berdasarkan peneltian ini dapat diketahui bahwa juvenil karang memiliki kecenderungan ditemukan lebih banyak pada tutupan karang mati dalam kondisi lingkungan yang optimum berdasarkan parameter fisika, kimia, dan biologi.
\end{abstract}

Kata kunci : Terumbu Karang, Densitas Juvenil, Parameter Fisika, Kimia dan Biologi

\section{Abstract \\ Habitat Quality of Juvenile Corals Recruitment in Waters of Kemujan Island, Karimunjawa}

Kemujan Island is one of the largest islands in the Karimunjawa which has a varying density of coral reefs. The coral reef ecosystem has an important role however it is vulnerable to damage. the juvenile recruitment of the coral can result from reductions in support of the habitat of the coral, as a result of a decline in the quality of the waters affected by anthropogenic activity. The purpose of this study is to determine the decline of coral juvenile the compatibility of chemical, physical, and biological factors that enhance the resilience of coral juvenile, the condition of coral reefs, and the correlation of coral juvenile with the coral covers and the organic material in the waters of Kemujan Island.. The method used in this research is a descriptive analysis method. The method used in data collection is Line Intercept Transect (LIT) 50 meters. Research was carried out in November 2019 on the west (S: 05०46'07,4" and E :

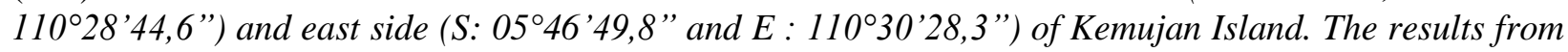
this study obtained that the highest abundance of juvenile corals was in the reef flat area of the west side from the waters of the Kemujan Island as many as 0,44 colonies $/ \mathrm{m}^{2}$ while the lowest abundance was in the reef slope area of the eastern side as many as 0,15 colonies $/ \mathrm{m}^{2}$. The physical (depth, brightness, currents velocity, temperature), chemical (DO, pH, salinity, organic material) and biological (total 
colony of bacteria) parameters in the study location were still in the optimum range by KepMen LH Number 51 in 2004. The condition of live coral cover on the west side of Kemujan Island waters ranged from $46.60 \%$ to $53.62 \%$ while on the east side it ranged from $44.10 \%$ to $71.38 \%$. The abundance of juveniles coral as dependent variable with live coral cover, coral fragments, and organic matter as independent variable showed inversed pattern relationship whereas with dead coral cover was directly proportional. Based on this study it can be known that corals juvenile have a tendency to be found more at dead coral in optimum environmental conditions within the physical, chemical, and biological parameters.

Keywords : Coral Reefs, Juvenil Abudance, Physical, Chemical, and Biological Parameters

\section{PENDAHULUAN}

Kepulauan Karimunjawa merupakan salah satu kepulauan yang terletak di Kabupaten Jepara Provinsi Jawa Tengah. Kepulauan Karimunjawa ini tepatnya terletak kurang lebih sejauh 45 mil dari laut utara Jepara. Kepulauan ini memiliki 27 gugusan pulau-pulau kecil yang apabila diakumulasikan keseluruhan wilayah dari Kepulauan Karimunjawa yaitu kurang lebih mencapai 111. 625 Ha (Yusuf, 2013). Terumbu karang merupakan salah satu ekosistem di Kepulauan Karimunjawa yang keberadaannya sangat penting untuk biota lainnya, selain itu juga dimanfaatkan oleh masyarakat sekitar untuk wisata bahari. Kondisi terumbu karang pada beberapa lokasi di perairan Pulau Kemujan berada pada kategori sedang dengan kriteria 25-49,5\% dan baik dengan kriteria 50-74,5\%. Terumbu karang di Perairan Pulau Kemujan hanya memiliki tutupan karang sebesar 30,646\% yang masuk dalam kategori sedang (Giyanto et al., 2017). Menurut Ardiyanto (2015) bahwa persentase tutupan life form terumbu karang pada Pulau Kemujan, Kepulauan Karimunjawa yaitu sebesar $61,01 \%$ yang masuk dalam kategori baik dan banyak didominasi oleh life form branching.

Tutupan terumbu karang dapat mengalami penurunan kondisi yang dipengaruhi oleh penurunan kualitas lingkungan akibat faktor alam maupun kegiatan manusia. Berdasarkan penelitian Suryanti et al. (2011), pada tahun 2009 terjadi penurunan luas terumbu karang di Kepulauan Karimunjawa dari 459,952 ha menjadi 338,408 ha. Penurunan kondisi tutupan terumbu karang dapat berpengaruh terhadap tingkat rekruitmen juvenil karang (Gilmour et al., 2016). Stadia juvenil karang sangat rentan terjadi mortalitas yang dapat disebabkan oleh pengaruh kualitas lingkungan. Lingkungan yang buruk atau tidak sesuai dengan baku mutu untuk kehidupan karang akan mengurangi kemungkinan juvenil karang menempel pada perairan tersebut. Rekruitmen merupakan hal yang penting untuk menjamin keberadaan dari biota karang itu sendiri. Kondisi terumbu karang di Perairan Pulau Kemujan berada pada kriteria sedang, sehingga apabila semakin berkurang juvenil karang yang menempel maka tidak menutup kemungkinan kondisi terumbu karang di perairan tersebut akan semakin menurun.

Tujuan penelitian ini adalah untuk mengetahui densitas juvenil karang berdasarkan perbedaan kedalaman, kesesuaian faktor fisika (kedalaman, kecerahan, kecepatan arus, dan suhu), kimia (DO, pH, salinitas, dan bahan organik) dan biologi (total koloni bakteri) yang mempengaruhi proses penempelan juvenil karang, kondisi terumbu karang berdasarkan perbedaan kedalaman serta hubungan antara kelimpahan juvenil karang dengan tutupan karang dan bahan organik di perairan Pulau Kemujan. Hasil penelitian ini diharapkan dapat dijadikan sebagai bahan pertimbangan dalam melakukan pengelolaan kondisi terumbu karang. Penempelan juvenil karang secara permanen di perairan Pulau Kemujan akan berpengaruh pada kelestarian terumbu karang untuk itu perlu adanya pengelolaan dalam meningkatkan keberhasilan penempelan juvenil karang.

\section{MATERI DAN METODE}

Penelitian ini telah dilakukan di Perairan Pulau Kemujan, Taman Nasional Karimunjawa, Jepara pada Bulan November 2019 yang masuk dalam Musim Peralihan II pada sisi barat di titik (S) : 05 $46^{\prime} 07,4^{\prime \prime}$ dan (E) : $110^{\circ} 28^{\prime} 44,6^{\prime \prime}$ dan sisi timur pada titik (S): $05^{\circ} 46^{\prime} 49,8^{\prime \prime}$ dan (E) : $110^{\circ} 30^{\prime} 28,3^{\prime \prime}$. Stasiun pengamatan sebanyak 2 stasiun dimana setiap stasiun terdapat 2 titik pengambilan data dan 2 kali pengulangan. Peta lokasi penelitian dapat dilihat pada Gambar 1 .

Materi yang dikaji dalam penelitian ini yaitu densitas juvenil karang per $\mathrm{m}^{2}$, kondisi lingkungan serta substrat bagi penempelan juvenil karang pada perairan Pulau Kemujan yang meliputi faktor fisika (kedalman, kecerahan, 


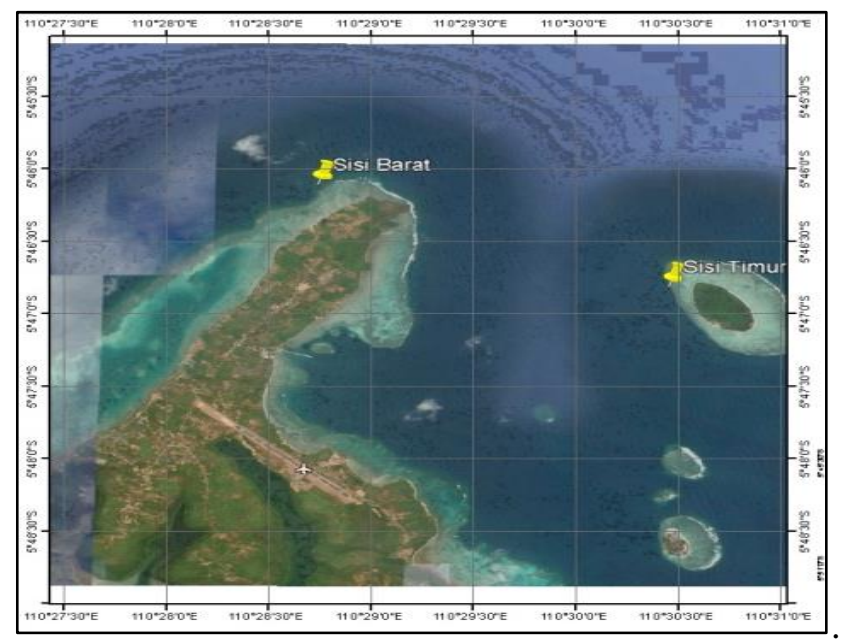

Gambar 1. Peta Lokasi Penelitian

kecepatan arus, suhu), kimia (DO, $\mathrm{pH}$, salinitas, bahan organik) yang dilakukan secara in situ dan biologi (total koloni bakteri) yang dilakukan secara ex situ

Metode penelitian yang digunakan yaitu metode analisis deskriptif. Pemilihan lokasi yaitu menggunakan purposive sampling method. Lokasi yang digunakan untuk pengambilan data penelitian yaitu berada pada daerah reef flat dan reef slope. Pemilihan lokasi ini berdasarkan pada faktor keterwakilan dimana adanya perbedaan kedalaman yang signifikan terhadap kedua daerah penelitian tersebut yaitu kedalaman 5 meter (Reef flat) dan kedalaman 10 meter (Reef slope). Faktor lain yang menjadi pertimbangan yaitu keselamatan kerja pada saat pengambilan data (LIPI, 2014). Pengamatan juvenil karang dilakukan dengan pendekatan sampling berdasarkan metode Line Intercept Transect (LIT) (English et al., 1994). LIT yang digunakan yaitu sepanjang 50 meter dan lebar jarak pandang yaitu 1 meter tiap sisi kanan dan kiri line. Pengamatan dilakukan dengan cara zigzag dan dihitung jumlah juvenil karang yang ditemukan serta tutupan karang. Pengamatan pada setiap stasiun dilakukan dengan 2 kali pengulangan.

Analisis data untuk pengukuran persentase kondisi tutupan terumbu dapat menggunakan rumus English et al. (1994) yaitu sebagai berikut:

$$
\mathrm{Pc}=\frac{\mathrm{Li}}{\mathrm{L} \text { total }} \times 100 \%
$$

Keterangan : $\mathrm{Pc}=$ Persen tutupan karang; $\mathrm{Li}=$ panjang tutupan life form; Ltotal = Panjang transek

Hasil nilai persentase tutupan karang yang telah didapatkan kemudian untuk kriteria penentuan kondisi terumbu karang dilakukan berdasarkan Keputusan Menteri LH No. 4 tahun 2001. Data juvenil karang dan terumbu karang yang diperoleh diidentifikasi dengan menggunakan buku identifikasi karang Suharsono (2008). Perhitungan komposisi juvenil karang dilakukan berdasarkan kriteria ukuran $<5 \mathrm{~cm}$ (Norstrom et al., 2006). Sedangkan untuk mengetahui densitas juvenil karang digunakan rumus (Odum, 1971) sebagai berikut :

$$
\text { Densitas }\left(\frac{\text { Koloni }}{m^{2}}\right)=\frac{\text { Jumlah Koloni }}{\text { Total Luas Area Pengamatan }}
$$

Pengambilan substrat sebagai variabel bebas, dari tempat penempelan atau rekrutmen juvenil karang dilakukan sebanyak satu kali pada setiap pengulangan di titik sampling. Substrat penempelan yang diambil pada satu kali pengulangan kemudian dimasukkan kiyae dalam plastik ziplock lalu disimpan pada coolbox. Substrat tersebut dianalisis di laboratorium, dimana hasilnya digunakan untuk pengukuran kandungan bahan organik dan total kelimpahan bakteri.

Pengukuran bahan organik dilakukan dengan metode spektrofotometer (Balai Penelitian Tanah, 2005) dengan menggunakan rumus:

Kadar C-organik $(\%)=$ ppm kurva $\times 10500^{-1} \times \mathrm{fk}$

Keterangan : ppm kurva $=$ Kadar contoh yang didapatkan dari kurva hubungan antara dengan pembacaannya setelah dikoreksi blanko; $100=$ Konversi ke \%; fk = Faktor koreksoi kadar air (100/(100 - \% kadar air)) 
Pengukuran total koloni bakteri menggunakan metode TPC (Total Plate Count) dengan menggunakan rumus berdasarkan SNI 7547.1-2009 sebagai berikut:

$$
\mathrm{N}(\mathrm{cfu} / \mathrm{mL})=\frac{\mathrm{n}(\mathrm{cfu})}{0,1(\mathrm{~mL})} \times 10^{\mathrm{x}}
$$

Keterangan: jika volume yang diinokulasikan $10^{-1}$ $\mathrm{mL} ; \mathrm{N}=$ Jumlah koloni, dinyatakan dalam koloni per $\mathrm{mL} ; \mathrm{n}=$ jumlah koloni bakteri dalam cawan agar; $10^{\mathrm{x}}=$ seri pengenceran

Kecerahan, kedalaman, suhu dan kecepatan arus, sebagai parameter fisika ; serta oksigen terlarut (DO), $\mathrm{pH}$ dan salinitas sebagai parameter kimia diukur secara in situ bersamaan dengan waktu sampling.

Perbedaan kelimpahan juvenil karang berdasarkan perbedaan kedalaman serta lokasi dilakukan uji T. Hipotesis yang digunakan yaitu apabila nilai Sig < 0,05 maka terdapat perbedaan pada antar kedalaman maupun antar sisi stasiun, sedangkan sig >0,05 maka tidak terdapat perbedaan yang signifikan. Hubungan kondisi karang dan bahan organik terhadap kelimpahan juvenil karang dilakukan dengan analisis regresi melalui nilai koefisien korelasi (r) dengan kriteria sebagai berikut: $r=<0,2$ Hubungan rendah sekali, lemah sekali; $r=0,2-0,4$ Hubungan yang cukup berarti; $r=0,4-0,7$ Hubungan yang tinggi, kuat; $\mathrm{r}=>0,9$ Hubungan sangat tinggi, kuat sekali, dapat diandalkan

\section{HASIL DAN PEMBAHASAN}

Berdasarkan pengamatan yang telah dilakukan, didapatkan densitas juvenil karang yang berkisar $0,15-0,44 \mathrm{koloni} / \mathrm{m}^{2}$. Data densitas antar stasiun dan antar kedalaman dapat dilihat pada Gambar 2.

Densitas juvenil karang di stasiun 1 (sisi barat) berada pada kisaran 0,30-0,44 koloni $/ \mathrm{m}^{2}$, dengan rata-rata $0,37 \mathrm{koloni} / \mathrm{m}^{2}$, sedangkan pada stasiun 2 (sisi timur) sejumlah $0,15-0,27$ koloni $/ \mathrm{m}^{2}$, dengan rata-rata 0,21 koloni $/ \mathrm{m}^{2}$ (Gambar 2). Hasil tersebut menunjukkan bahwa stasiun 1 lebih baik dari stasiun 2. Hal ini disebabkan pada stasiun 1 mempunyai ketersediaan substrat sebagai media penempelan juvenil yang lebih banyak dibandingkan stasiun 2 . Substrat media penempelan tersebut yaitu berupa karang mati dengan kisaran 28,95-32,27\% pada stasiun 1, sedangkan pada stasiun 2 berkisar 12,57-17,17\% (Tabel 1). Tingginya tutupan karang hidup memberikan dampak pada penurunan densitas juvenil karang (Gambar 3), sedangkan tingginya tutupan karang mati akan berdampak pada peningkatan densitas juvenil karang (Gambar 4). Hal ini sebagaimana dinyatakan oleh Bachtiar et al. (2012) yang menyatakan bahwa terdapat kecenderungan setelah melewati batas tertentu semakin tinggi kondisi tutupan karang hidup maka kelimpahan juvenil karang akan semakin kecil. Hal ini disebabkan karena adanya kompetisi ruang antara karang dewasa dengan juvenil karang serta sempitnya ruang bagi penempelan larva karang tersebut.

Hasil analisis regresi untuk mengetahui korelasi antara persentase tutupan karang hidup terhadap densitas juvenil karang didapatkan hasil nilai koefisien korelasi yaitu sebesar 0,431 . Nilai koefisien korelasi tersebut dapat diartikan bahwa persentase tutupan karang hidup memiliki hubungan yang tinggi dan kuat terhadap densitas juvenil karang.

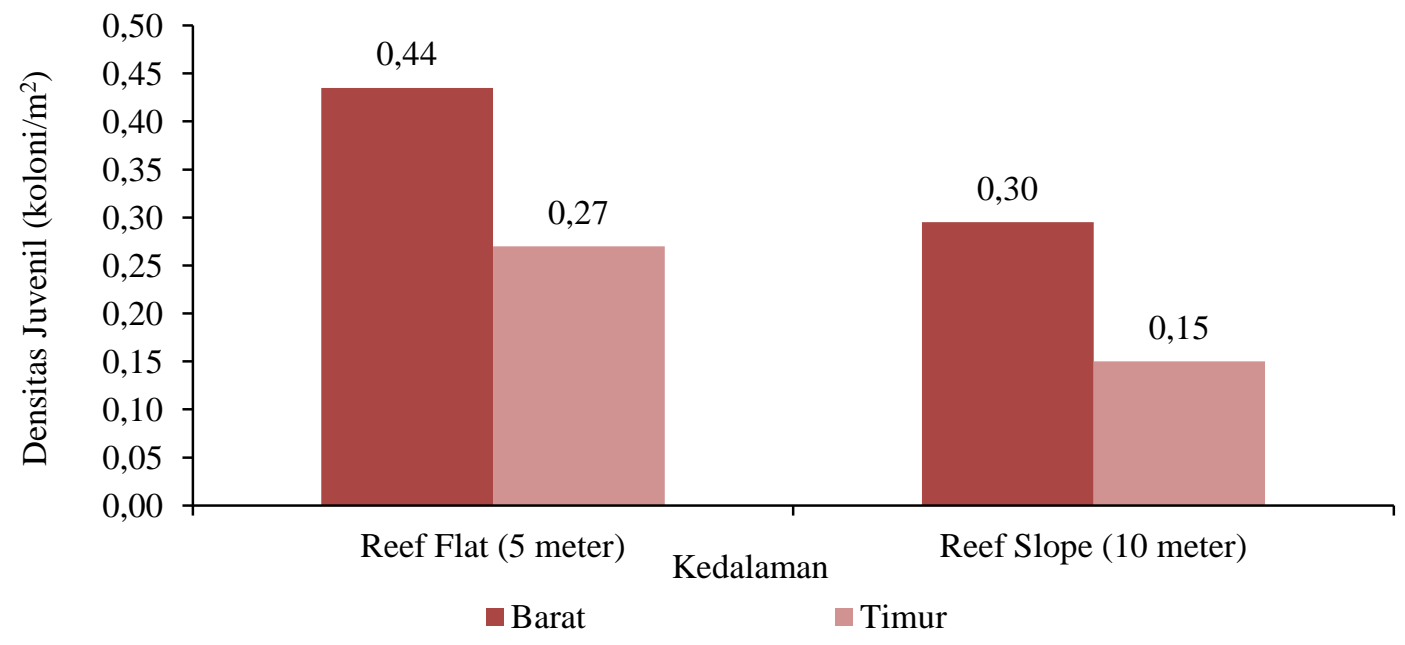

Gambar 2. Histogram Densitas Juvenil Karang 


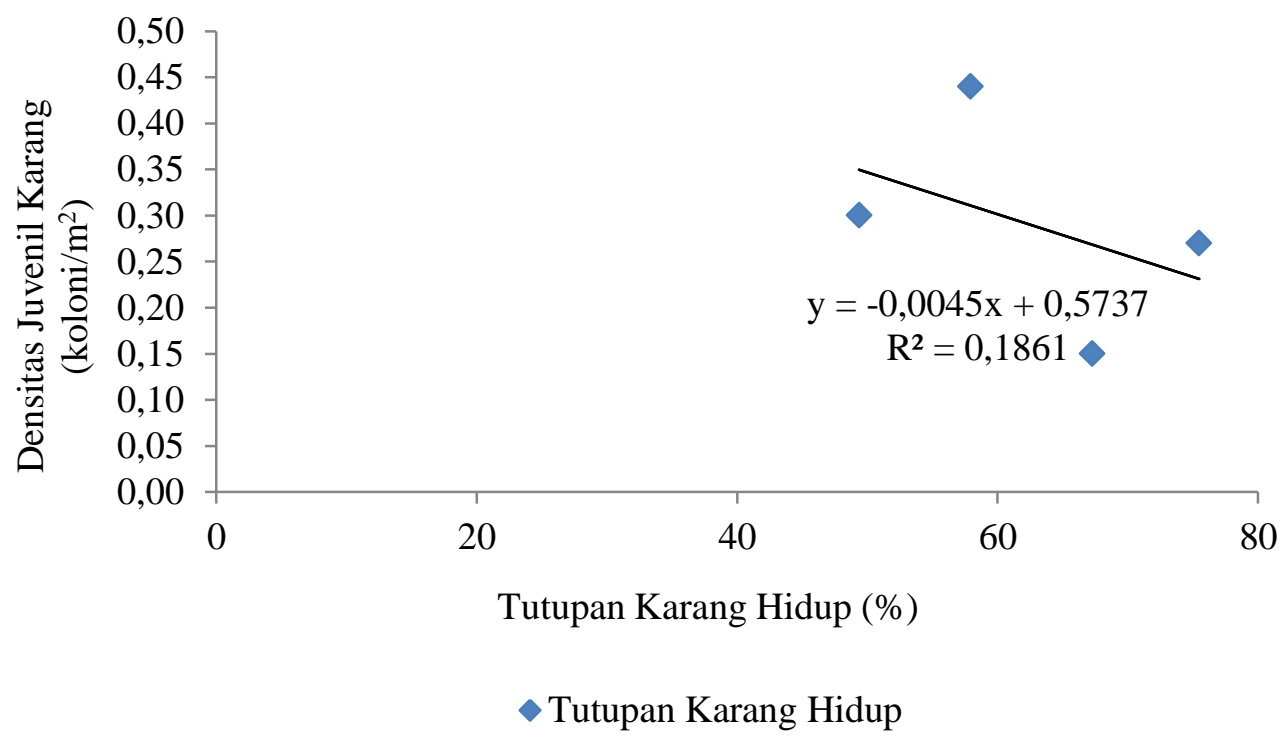

Gambar 3. Grafik Hubungan Tutupan Karang Hidup dengan Densitas Juvenil Karang.

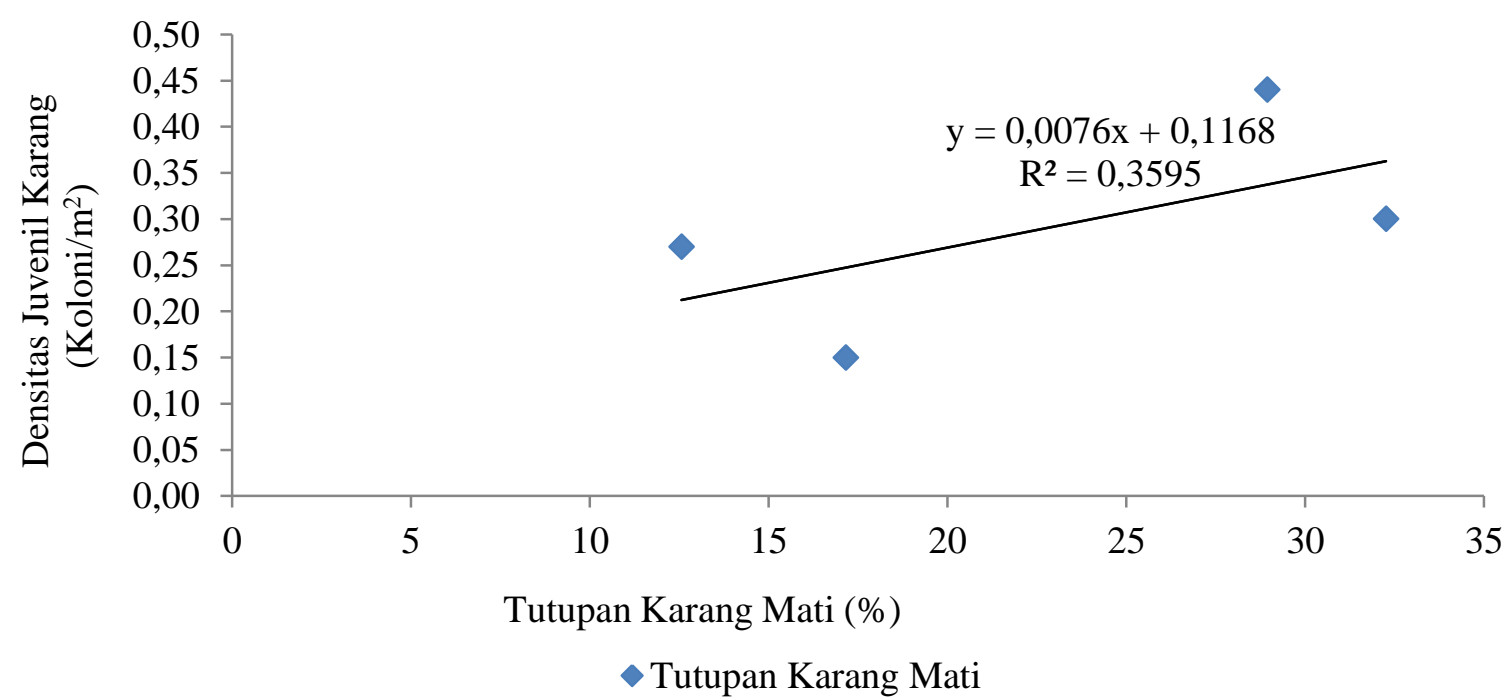

Gambar 4. Grafik Hubungan Tutupan Karang Mati dengan Densitas Juvenil Karang.

Menurut Karmila et al. (2019) yang menyatakan bahwa tingkat rekruitmen karang tertinggi terjadi pada lokasi dimana banyak ditemukannya karang mati (dead coral) dan sebaliknya pada lokasi dengan terumbu karang yang memiliki kondisi baik memiliki tingkat rekruitmen karang yang lebih rendah. Phardana et al. (2014) menyampaikan bahwa keberhasilan kolonisasi atau rekrutmen juvenil karang pada suatu wilayah dipengaruhi oleh beberapa syarat. Syarat tersebut diantaranya yaitu tipe substrat dan faktor biologis seperti ketersediaan lapisan tipis (biofilm) di atas permukaan substrat. Hasil analisis regresi untuk mengetahui korelasi antara persentase karang mati terhadap densitas juvenil karang didapatkan nilai koefisien korelasi yaitu sebesar 0,599. Nilai koefisien korelasi tersebut dapat diartikan bahwa persentase tutupan karang mati memiliki hubungan yang tinggi dan kuat terhadap densitas juvenil karang.

Tipe substrat berpengaruh terhadap densitas juvenil karang. Juvenil karang cenderung melakukan penempelan pada substrat yang bersifat stabil. Densitas juvenil karang lebih rendah pada substrat pecahan karang dikarenakan pecahan karang merupakan substrat yang tidak stabil (Gambar 5). Juvenil karang cenderung akan menempel pada substrat yang stabil untuk memperkecil kemungkinan terjadinya kematian akibat pengaruh gelombang dan arus (Acosta et al., 2011). Substrat jenis pecahan karang sebagi tempat rekrutmen karang merupakan substrat 
yang riskan bagi juvenil karang untuk bertahan hidup dikarenakan pecahan karang merupakan substrat yang tidak stabil (Thamrin, 2006). Hasil analisis regresi untuk mengetahui korelasi antara persentase tutupan pecahan karang terhadap densitas juvenilkarang didapatkan hasil nilai koefisien korelasi yaitu sebesar 0,637. Nilai koefisien korelasi tersebut dapat diartikan bahwa persentase tutupan pecahan karang memiliki hubungan yang tinggi dan kuat terhadap densitas juvenil karang, namun memiliki pola yang berlawanan (menurun).

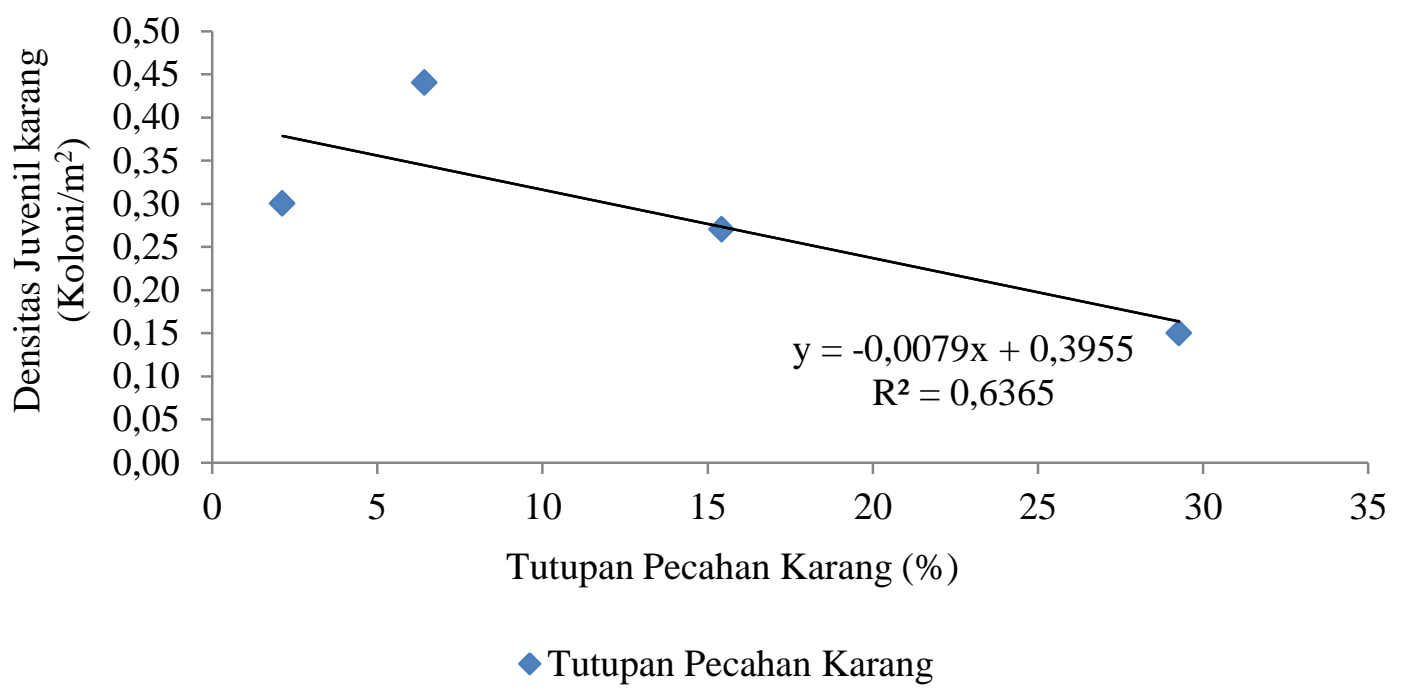

Gambar 5. Regresi Hubungan Tutupan Pecahan Karang dengan Densitas Juvenil Karang.

Tabel 1. Persentase Total Tutupan Karang pada Perairan Pulau Kemujan

\begin{tabular}{lcccc}
\hline \multirow{2}{*}{ Life form } & \multicolumn{2}{c}{ Stasiun 1 (Barat) } & \multicolumn{2}{c}{ Stasiun 2 (Timur) } \\
\cline { 2 - 5 } & Reefflat & Reef slope & Reefflat & Reef slope \\
\hline Tutupan Karang Mati (\%) & 28,95 & 32,27 & 12,57 & 17,17 \\
Rubble (\%) & 6,43 & 2,13 & 15,43 & 29,27 \\
Tutupan Karang Hidup (\%) & 53,62 & 46,6 & 71,38 & 44,1 \\
\hline
\end{tabular}

Lapisan biofilm adalah lapisan yang terbentuk pada suatu permukaan substrat akibat adanya interaksi antar sel mikroorganisme yang dapat berupa bakteri. Nilai total koloni bakteri pada stasiun 1 berada pada kisaran $4,9 \times 10^{4}$ $5,7 \times 10^{4}$, dengan rata-rata $5,3 \times 10^{4}$, sedangkan pada stasiun 2 sejumlah $3,6 \times 10^{4}-7,8 \times 10^{4}$, dengan rata-rata $5,7 \times 10^{4}$ (Tabel 2). Hasil tersebut menunukkan bahwa nilai total koloni bakteri pada stasiun 2 lebih tinggi dibandingkan dengan stasiun 1. Hal ini disebabkan pada stasiun 2 memiliki nilai bahan organik total pada kisaran 2,192$3,123 \%$, sedangkan pada stasiun 1 sebesar 0,758 0,947\% (Tabel 2). Densitas juvenil karang tertinggi berada pada stasiun 1 yang memiliki nilai total koloni bakteri dan bahan organik total yang lebih rendah dari stasiun 2 dikarenakan ketersediaan substrat sebagai media penempelan juvenil pada stasiun 1 lebih tinggi dari stasiun 2 (Gambar 6). Hal ini sebagaimana dianyatakan oleh Erwin et al. (2008) dalam Rahman et al. (2014) yang menyatakan bahwa komposisi lapisan biofilm dapat bervariasi menurut letak, kedalaman maupun berdasarkan waktu. Nilai bahan organik lebih tinggi pada stasiun 2 dibandingkan dengan stasiun 1 akan tetapi persentase tutupan karang karang mati pada stasiun 2 lebih rendah dibandingkan dengan stasiun 1 . Hal ini diduga menjadi penyebab dimana kelimpahan juvenil karang lebih rendah pada stasiun 2 meskipun memiliki nilai bahan organik yang tinggi.

Berdasarkan hasil analisis regresi untuk mengetahui korelasi kandungan bahan organik total pada substrat rekrutmen terhadap densitas juvenil karang didapatkan hasil nilai koefisien korelasi yaitu sebesar 0,553. Nilai koefisien korelasi tersebut dapat diartikan bahwa kandungan bahan organik memiliki hubungan yang tinggi dan kuat terhadap densitas juvenil karang. 
Adanya bakteri pada substrat tersebut sebagi salah satu syarat terjadinya penempelan juvenil karang. Bakteri merupakan salah satu jenis penyusun lapisan biologi atau yang dapat disebut sebagi lapisan biofilm. Lapisan biofilm ini terbentuk diatas permukaan substrat media penempelan juvenil. (Phardana et al., 2014). Menurut Rahman et al. (2014) bahwa tingkat rekrutmen karang dipengaruhi oleh keadaan substrat yang akan digunakan sebagai media rekrutmen. Planula karang memiliki kecenderungan melakukan penempelan atau rekrutmen pada substrat yang lebih stabil serta telah dilapisi oleh lapisan biofilm. Lapisan biofilm terbentuk dari bakteri sehingga mampu menstimulasi dan berpengaruh terhadap kepadatan larva planula karang untuk rekrutmen.

Kualitas perairan yang mencakup faktor fisika, kimia maupun biologi memiliki pengaruh terhadap keberhasilan dari proses rekrutmen atau penempelan dari juvenil karang. Kualitas perairan yang tidak berada pada kisaran optimum dapat berdampak pada penurunan kelangsungan hidup dari juvenil karang (Gilmour et al., 2016). Berdasarkan hasil pengukuran parameter fisika secara in situ pada kedua stasiun dapat dilihat bahwa temperatur berada pada kisaran $29-30^{\circ} \mathrm{C}$.
Kecerahan berkisar 4,41 meter hingga $\infty$ dan kecepatan arus $0,08-0,125 \mathrm{~m} / \mathrm{s}$. Baku mutu air laut untuk kehidupan terumbu karang berdasarkan Kepmen LH No 51 Tahun 2004 bahwa untuk kecerahan yaitu $>5$ meter sedangkan temperatur yaitu 28-30\% . Secara keseluruhan hasil pengukuran yang didapatkan masih berada pada kisaran baku mutu untuk menunjang kehidupan karang. Hasil pengukuran parameter kimia didapatkan hasil yaitu DO pada kedua stasiun berada pada kisaran 9,61-10,48 mg/L, salinitas berada pada kisaran 34\%, pH berkisar 7,33-7,44. Baku mutu air laut untuk kehidupan terumbu karang berdasarkan Kepmen LH No 51 Tahun 2004 bahwa untuk DO yaitu >5mg/L; pH pada kisaran 7-8,5 sedangkan salinitas 33-34\%o. Nilai kondisi perairan pada kedua stasiun dapat dilihat pada Tabel 3.

Persentase tutupan terumbu karang berdasarkan tabel 1 pada stasiun 1 kedalaman 5 meter (reefflat) memiliki rata-rata nilai persentase tutupan karang hidup yaitu sebesar 53,62\% sedangkan pada kedalaman 10 meter (reef slope) yaitu sebesar $46,60 \%$. Tutupan karang mati pada stasiun 1 lebih tinggi daripada tutupan pecahan karang. Tutupan karang mati pada kedalaman 10 meter lebih tinggi dibandingkan pada kedalaman

Tabel 2. Pengukuran Bahan Organik Substrat Rekrutmen Juvenil Karang

\begin{tabular}{llcc}
\hline \multicolumn{2}{c}{ Lokasi Stasiun } & $\begin{array}{c}\text { Kelimpahan Bakteri } \\
\text { (cfu/mL) }\end{array}$ & Bahan Organik (\%) \\
\hline \multirow{2}{*}{ Stasiun 1 (Barat) } & Reefflat & $5,7 \times 10^{4}$ & 0,947 \\
& Reef slope & $4,9 \times 10^{4}$ & 0,758 \\
\hline \multirow{2}{*}{ Stasiun 2 (Timur) } & Reefflat & $7,8 \times 10^{4}$ & 3,123 \\
& Reef slope & $3,6 \times 10^{4}$ & 2,192 \\
\hline
\end{tabular}

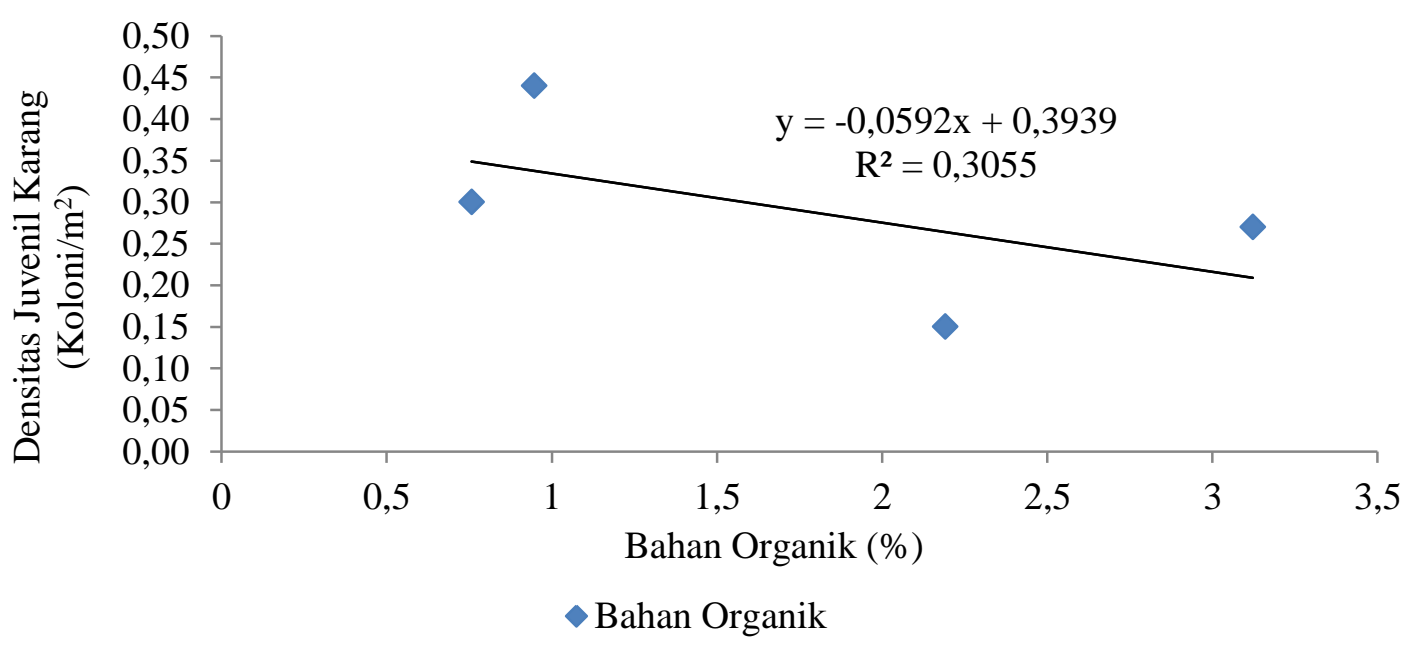

Gambar 6. Grafik Hubungan Densitas Juvenil Karang dengan Bahan Organik. 
Tabel 3. Hasil Pengukuran Parameter Fisika Kimia Kedua Stasiun

\begin{tabular}{lcccccc}
\hline \multirow{2}{*}{ Variabel } & \multicolumn{3}{c}{ Stasiun 1 (Barat) } & \multicolumn{3}{c}{ Stasiun 2 (Timur) } \\
\cline { 2 - 5 } & \multicolumn{3}{c}{ Pengulangan } \\
\cline { 2 - 5 } & 1 & 2 & 3 & 1 & 2 & 3 \\
\hline Kecerahan & 4,42 & 4,41 & 4,42 & $\infty$ & $\infty$ & $\infty$ \\
$\mathrm{pH}$ & 7,42 & 7,44 & 7,42 & 7,33 & 7,34 & 7,33 \\
DO (mg/L) & 9,61 & 9,63 & 9,62 & 10,48 & 10,47 & 10,45 \\
Salinitas & 34 & 34 & 34 & 34 & 34 & 34 \\
Kecepatan Arus (m/s) & 0,083 & 0,08 & 0,081 & 0,125 & 0,120 & 0,122 \\
Suhu perairan & 30 & 29 & 30 & 29 & 29 & 30 \\
\hline
\end{tabular}

5 meter namun memiliki nilai persentase pecahan karang yang lebih sedikit dibandingkan pada kedalaman 5 meter.

Stasiun 2 pada kedalaman 5 meter (reef flat) diperoleh rata-rata nilai persentase tutupan karang hidup yaitu sebesar $71,38 \%$ sedangkan pada kedalaman 10 meter (reef slope) yaitu sebesar $44,10 \%$. Tutupan karang mati pada stasiun 2 jauh lebih kecil dibandingkan dengan nilai persentase pecahan karang, dimana pada reef slope persentase tutupan pecahan karang jauh lebih tinggi dibandingkan pada reefflat.

Berdasarkan KEPMEN LH No 4 Tahun 2001 terkait kriteria baku mutu kerusakan terumbu karang dapat diketahui bahwa pada kedalaman 5 meter (reef flat) stasiun 1 termasuk dalam kategori baik, sedangkan pada kedalaman 10 meter (reef slope) stasiun 1 termasuk dalam kategori rusak sedang. Lokasi stasiun 2 pada kedalaman 5 meter (reef flat) termasuk dalam kategori baik, sedangkan pada kedalaman 10 meter (reef slope) stasiun 2 termasuk dalam kategori rusak sedang.

\section{KESIMPULAN}

Berdasarkan penelitian ini dapat disimbulkan bahwa densitas juvenil karang pada stasiun 1 (barat) sebesar $0,44 \mathrm{koloni} / \mathrm{m}^{2}$ lebih tinggi dibandingkan dengan stasiun 2 (timur) sebesar $0,27 \mathrm{koloni} / \mathrm{m}^{2}$ yang didukung oleh parameter fisika (kecerahan, kecepatan arus, suhu), kimia (bahan organik, $\mathrm{pH}$, salinitas, DO) serta biologi (total koloni bakteri) yang berada dalam kisaran baku mutu sesuai KEPMEN LH No 51 tahun 2004 untuk menunjang kehidupan karang. Kondisi tutupan terumbu karang pada staiun 1 berada pada kisaran rusak sedang hingga baik, demikian juga stasiun 2. Tingkat persentase karang mati pada stasiun 1 lebih tinggi dibandingkan dengan stasiun 2 sedangkan untuk persentase pecahan karang diperoleh hasil yang sebaliknya. Uji regresi korelasi menunjukkan bahwa densitas juvenil karang dipengaruhi oleh tutupan karang hidup, tutupan pecahan karang serta bahan organik yang menunjukkan pola hubungan berbanding terbalik sedangkan tutupan karang mati menunjukkan pola hubungan berbanding lurus. Hasil dari nilai korelasi berada kisaran kategori hubungan yang kuat.

\section{UCAPAN TERIMAKASIH}

Artikel ini merupakan bagian dari skripsi pada Program Studi Manajemen Sumberdaya Perairan FPIK Undip. Terimakasih disampaikan kepada Balai Taman Nasional Karimunjawa yang telah memberikan ijin untuk melakukan penelitian di kawasan Perairan Pulau Kemujan. Terimakasih disampaikan kepada Scientific Writing Class yang diselenggarakan oleh Prodi Manajemen Sumberdaya Perairan dalam membantu penulisan artikel. Terimakasih disampaikan kepada semua pihak yang turut membantu dalam pengumpulan data penelitian ini.

\section{DAFTAR PUSTAKA}

Acosta, A., Luisa, F.D. \& Valeria, P. 2011. Review on Hard Coral Recruitment (Cnidarian: Scleractinian) in Columbia. Universitas Sciantiarum. 16:200-218.

Ardiyanto. R. 2015. Pemetaan Terumbu Karang Mengggunakan Metode Klasifikasi Berbasis Objek pada Citra Quickbird-2 Multispektral. Jurnal Bumi Indonesia. 4(1): 327-335.

Bachtiar, I., Abrar, M. \& Budiyanto, A. 2012. Rekruitmen Karang Scleractinia di Perairan Pulau Lembata. Jurnal Ilmu Kelautan. 17(1): 1-7.

Balai Penelitian Tanah. 2005. Petunjuk Teknis Analisis Kimia Tanah, Tanaman, Air dan Pupuk. Bogor: Balai Penelitian Tanah. 143 Hal. 
English, S., Wilkinson, C. \& Baker, V. 1994. Survey Manual for Tropical Marine Resources. ASEAN-Australia Marine Science Project Living Coastal Resources. Australia Institute of Marine Science ; Townsville. 390p.

Erwin. P.M., Song, B., \& Szmant, A.M. 2008. Settlement Behavior of Acropora palmata Planulae: Effects of Biofilm Age and Crustose Coralline Alga Cover. Proceedings of the 11th International Coral Reef Symposium. 1219-1223.

Gilmour, J., Speed C.W. \& Babcock, R. 2016. Coral Reproduction in Western Australia. Peer J. 2-43.

Giyanto., Abrar, M., Hadi, T.A., Budiyanto, A., Hafizt, M., Salatalohy, A. \& Iswari, M.Y. 2017. Status Terumbu Karang Indonesia 2017. Coremap CTI Pusat Penelitian Oseanografi LIPI. $41 \mathrm{hlm}$.

Karmila., Sadarun, B. \& Rahmadani. 2019. Jenis dan Kepadatan Rekruitmen Karang Berdasarkan Bentuk Pertumbuhan Karang Scleractinia di Perairan Desa Lalanu Kabupaten Konawe Sulawesi Tenggara. Jurnal Sapa Laut. 4(3):106-112.

Keputusan Menteri Negara Lingkungan Hidup No 4 tahun 2001 Terkait Kriteria Baku Kerusakan Terumbu Karang. $12 \mathrm{Hal}$.

Keputusan Menteri Negara Lingkungan Hidup No 51 tahun 2004 Terkait Baku Mutu Air Laut untuk Terumbu Karang. 13 Hal.

Norstrom, A.V., Lokrantz, J., Nystrom, M. \& Yap, H.T. 2006. Influence of Dead Coral
Substrate Morphology on Patterns of Juvenile Coral Distribution. Marine Biology. 150:1145-1152.

Odum, E.P. 1971. Fundamentals of Ecology. WB Saunders Co: Philadelphia. 574 Page.

Phardana, T., Suparno \& Efendi, Y. 2014. Kondisi dan Struktur Komunitas Rekruitmen Karang Batu (Scleractinian) di Taman Wisata Perairan (TWP) Pulau Pieh. Jurnal KKP. 4(2):1-9.

Rahman. A., Haris, A. \& Jamaluddin. 2014. Pola Rekrutmen Karang Scleractinia pada Kondisi Lingkungan Berbeda. Jurnal Sains dan Teknologi. 14(3): 209-219.

SNI 7545.1-2009. Metode Identifikasi Bakteri pada Ikan Secara Konvensional-bagian 1: Edwardsiella ictaluri. Badan Standarisasi Nasional. 10 Hal.

Suharsono. 2008. Jenis-Jenis Karang di Indonesia. LIPI Press. Jakarta. $382 \mathrm{Hal}$.

Suryanti, Hendarto, B., \& Anggoro, D. 2011. Perubahan Luas Huran Mangrove di Pulau Kemujan Taman Nasional Karimunjawa. Pena Jurnal Ilmu Pengetahuan dan Teknologi. 1(20):1-9.

Thamrin. 2006. Karang: Biologi Reproduksi dan Ekologi. Pekanbaru: Minamandiri Pers. 260 Hal.

Yusuf, M. 2013. Kondisi Terumbu Karang dan Potensi Ikan di Perairan Taman Nasional Karimunjawa, Kabupaten Jepara. Buletin Oseanografi Marina. 2(2):54-60. 